\title{
Morphine Increases Brain Levels of Ferritin Heavy Chain Leading to Inhibition of CXCR4-Mediated Survival Signaling in Neurons
}

\author{
Rajarshi Sengupta, ${ }^{1 \star}$ Silvia Burbassi, ${ }^{1 \star}$ Saori Shimizu, ${ }^{1}$ Silvia Cappello, ${ }^{2}$ Richard B. Vallee, ${ }^{2}$ Joshua B. Rubin,${ }^{3}$ and \\ Olimpia Meucci ${ }^{1}$ \\ ${ }^{1}$ Department of Pharmacology and Physiology, Drexel University College of Medicine, Philadelphia, Pennsylvania 19102, ${ }^{2}$ Department of Pathology, \\ Columbia University Medical Center, New York, New York 10032, and ${ }^{3}$ Department of Pediatrics, Washington University School of Medicine, St. Louis, \\ Missouri 63110
}

This study focuses on the effect of $\mu$-opioid receptor agonists on CXCR4 signaling in neurons and the mechanisms involved in regulation of neuronal CXCR4 by opiates. The data show that CXCR4 is negatively modulated by long-term morphine treatments both in vitro and in vivo; CXCR4 inhibition is caused by direct stimulation of $\mu$-opioid receptors in neurons, leading to alterations of ligand-induced CXCR4 phosphorylation and upregulation of protein ferritin heavy chain (FHC), a negative intracellular regulator of CXCR4. Reduced coupling of CXCR4 to G-proteins was found in the brain of morphine-treated rats, primarily cortex and hippocampus. CXCR4-induced G $\alpha_{\mathrm{i}} / \mathrm{G} \beta \gamma$ activities were suppressed after $24 \mathrm{~h}$ treatment of cortical neurons with morphine or the selective $\mu$-opioid agonist DAMGO (D-Ala2- $N$ Me-Phe ${ }^{4}$-glycol ${ }^{5}$-enkephalin), as shown by analysis of downstream targets of CXCR4 (i.e., cAMP, Akt, and ERK1/2). These agonists also prevented CXCL12-induced phosphorylation of CXCR4, indicating a deficit of CXCR4 activation in these conditions. Indeed, morphine (or DAMGO) inhibited prosurvival signaling in neurons. These effects are not attributable to a reduction in CXCR4 expression or surface levels but rather to upregulation of FHC by opioids. The crucial role of FHC in inhibition of neuronal CXCR4 was confirmed by in vitro and in vivo RNA interference studies. Overall, these findings suggest that opiates interfere with normal CXCR4 function in the brain. By this mechanism, opiates could reduce the neuroprotective functions of CXCR4 and exacerbate neuropathology in opiate abusers who are affected by neuroinflammatory/infectious disorders, including neuroAIDS.

Key words: ferritin; opioids; chemokine; neurons; HIV; GPCRs

\section{Introduction}

The chemokine CXCL12 and its G-protein-coupled receptor (GPCR) CXCR4 play a crucial role in neuronal development and homeostasis (Lazarini et al., 2003; Tran and Miller, 2003; Stumm and Höllt, 2007). Activation of CXCR4 promotes neuronal survival through stimulation of major intracellular pathways, such as phosphatidylinositol 3-kinase/Akt and mitogen-activated protein kinases (MAPKs) (Chalasani et al., 2003; Floridi et al., 2003; Khan et al., 2004). CXCR4 also acts as a coreceptor for human immunodeficiency virus (HIV) envelope protein gp120 (Feng et al., 1996; Berger et al., 1999) and can be regulated by phosphorylation (Haribabu et al., 1997). Mutations of serine residues at CXCR4 C terminus that prevent phosphorylation can affect re-

\footnotetext{
Received Dec. 10, 2008; revised Jan. 15, 2009; accepted Jan. 22, 2009.

This work was supported by National Institutes of Health-National Institute on Drug Abuse Grants DA15014 and DA19808 (0.M.) and National Cancer Institute Grant 118389 (J.B.R.). We thank Dr. Kenny Simansky for sharing his expertise and laboratory instruments concerning the GTP $\gamma S$ binding assays, Dr. Jeegar Patel for his involvement in the initial part of this study, and Dr. Alessandro Fatatis for helpful and critical discussion.

*R.S. and S.B. contributed equally to this work.

Correspondence should be addressed to Dr. Olimpia Meucci, Department of Pharmacology and Physiology, Drexel University College of Medicine, 245 North 15th Street, Philadelphia, PA 19102. E-mail: omeucci@drexelmed.edu. D0I:10.1523/JNEUROSC1.5865-08.2009

Copyright $\odot 2009$ Society for Neuroscience $\quad$ 0270-6474/09/292534-11\$15.00/0
}

ceptor signaling and internalization (Doranz et al., 1999; Orsini et al., 1999). Furthermore, CXCL12-induced activation of CXCR4 causes phosphorylation of specific residues (i.e., Ser339/ human, Ser338/rat) implicated in CXCR4 regulation (Orsini et al., 1999; Woerner et al., 2005).

Opioids are small peptides primarily involved in nociception and immune responses (McCarthy et al., 2001); they act through specific receptors $(\mu, \delta$, and $\kappa)$ expressed in nervous and immune systems, which are also targets of substances of abuse, such as morphine (Hauser et al., 2005; Sharp, 2006). Opioid and chemokine systems can reciprocally influence each other's function at different levels; for instance, $\mu$-opioid ligands regulate expression and function of chemokine receptors in immune cells via heterologous desensitization (Grimm et al., 1998; Chen et al., 2004). Furthermore, chemokine and opioid receptors may form heterodimers, which would result in signaling outcomes different from those elicited by their respective homodimers (Pello et al., 2008).

CXCR4 and $\mu$-opioid receptors ( $\mu \mathrm{ORs)}$ are often coexpressed in the brain and cultured neurons (Patel et al., 2006; Burbassi et al., 2008). Treatment of neuronal cultures with the $\mu \mathrm{OR}$ agonist DAMGO (D-Ala2-N-Me-Phe ${ }^{4}$-glycol ${ }^{5}$-enkephalin) (or endogenous peptide endomorphin-1) affects prosurvival signaling via 
neuronal CXCR4 (Patel et al., 2006), supporting the hypothesis of a crosstalk between these constitutive receptor systems in the CNS. Thus, negative regulation of neuronal CXCR4 functions by opioids could contribute to HIV neuropathology by promoting neuronal damage and loss, as suggested by the increased neurological impairment that is observed in HIV-positive opiate abusers (Gurwell et al., 2001; Nath et al., 2002; Hauser et al., 2006).

The mechanism by which $\mu \mathrm{OR}$ agonists modulate CXCR4 signaling is unknown. Recent in vitro studies demonstrated that overexpression of ferritin heavy chain (FHC) in cell lines attenuated CXCR4 signaling, whereas enhanced CXCR4 function was observed in FHC-deficient cells ( $\mathrm{Li}$ et al., 2006). Ferritin is a ubiquitous protein primarily involved in iron storage/sequestration/detoxification (Torti and Torti, 2002; Zandman-Goddard and Shoenfeld, 2007), consisting of 24 protein subunits, both light $(19 \mathrm{kDa})$ and heavy $(21 \mathrm{kDa})$ chains. Alterations in iron to FHC ratio has been associated with neurodegenerative disorders, i.e., Parkinson's, Alzheimer's, and other inflammatory diseases (Thompson et al., 2003; Vidal et al., 2004; Zecca et al., 2005; Sultana et al., 2007). In addition, FHC is implicated in apoptosis (Aung et al., 2007; Bresgen et al., 2007). In the present study, we investigated the role that endogenous FHC plays in vivo in the $\mu \mathrm{OR}$-induced inhibition of CXCR4 signaling.

\section{Materials and Methods}

Cell cultures. Primary neurons were obtained from embryonic day 17 (E17)/E18 rat embryos and cultured either using a bilaminar cell culture system (i.e., in the presence of a feeder layer of secondary glia) as described previously (Khan et al., 2005) or in Neurobasal/B27 medium as reported here (modified from Brewer et al., 1993). Previous studies have demonstrated that cells maintained in Neurobasal medium yield cultures of high (>95\%) neuronal purity (Brewer et al., 1993; Brewer, 1997; Hemstapat et al., 2004). To further reduce growth of non-neuronal cells, cytosine arabinoside (AraC) $(1 \mu \mathrm{M})$ was added to the cultures within $24 \mathrm{~h}$ from plating. Briefly, neurons were plated at a density of $1 \times 10^{6}$ on 60 $\mathrm{mm}$ dishes in Neurobasal medium containing B27 (2\%) and horse serum $(2 \%)$. The medium was replaced after $2 \mathrm{~h}$ of plating with serum-free Neurobasal medium supplemented with B27, L-glutamine $(0.5 \mathrm{~mm})$, glutamic acid $(25 \mu \mathrm{M})$ (Tocris Bioscience), and $10 \mu \mathrm{g} / \mathrm{ml}$ gentamycin. On the fourth and eighth day in vitro (DIV), the culture medium was replaced again with Neurobasal media supplemented with B27, L-glutamine, gentamycin, and $\mathrm{AraC}$ (AraC was not included after the first week of culture). Neurons were used between DIV 10 and 12. Under these experimental conditions, glial contamination was minimal $(\sim 1-$ $2 \%$ ), as assessed by immunostaining with antibodies against specific neuronal/glial markers (supplemental Fig. 1, available at www.jneurosci.org as supplemental material).

Glial cells were cultured as described previously (Meucci and Miller, 1996) in $75 \mathrm{~cm}^{2}$ flasks in DMEM containing $10 \%$ fetal calf serum and 50 $\mu \mathrm{g} / \mathrm{ml}$ gentamycin. On day 14, cells were harvested and plated on $60 \mathrm{~mm}$ culture dishes $\left(0.5 \times 10^{6}\right.$ per plate). Unless otherwise specified, cell culture products are purchased from Invitrogen.

Western blots. For whole-cell lysates, cell lysates were prepared after drug treatment as described previously (Bardi et al., 2006) and summarized below. Primary neurons were washed with ice-cold PBS, collected in lysis buffer $(150 \mathrm{~mm} \mathrm{NaCl}, 50 \mathrm{~mm}$ Tris, $0.5 \% \mathrm{Na}$ deoxycholate, $0.1 \%$ SDS, $10 \mathrm{~mm} \mathrm{Na}_{4} \mathrm{P}_{2} \mathrm{O}_{7}, 5 \mathrm{~mm}$ EDTA, $1 \%$ Triton $\mathrm{X}-100$, and protease and phosphatase inhibitor mixture), and then incubated for $30 \mathrm{~min}$ on a rotor at $4^{\circ} \mathrm{C}$. After $30 \mathrm{~min}$, the lysates were spun at $20,800 \times g$ for $10 \mathrm{~min}$, the protein concentration of the supernatants was determined using bicinchoninic acid protein assay (BCA) following the instructions of the manufacturer (Pierce). Equal amounts of protein (40 $\mu \mathrm{g} / \mathrm{lane})$ were loaded for SDS-PAGE followed by immunoblotting.

For tissue homogenates, rat brain cortices were washed once with ice-cold PBS and incubated in TNN buffer (50 mm Tris/HCl, $\mathrm{pH} 7.4,50$ mM HEPES, $150 \mathrm{~mm} \mathrm{NaCl}, 1 \%$ Triton X-100, $1.5 \mathrm{~mm} \mathrm{MgCl}_{2}$, and $1 \%$ protease inhibitor) on ice for $10 \mathrm{~min}$, followed by centrifugation at $20,800 \times g$ for $10 \mathrm{~min}$. The protein concentration of the supernatant was measured by BCA. Equal amounts of protein ( $40 \mu \mathrm{g} / \mathrm{lane})$ were used for SDS-PAGE, followed by immunoblotting.

For cell surface protein purification, the Cell Surface Protein Isolation kit from Pierce was used following the protocol of the manufacturer. Briefly, cell surface proteins were biotinylated and then isolated using a neutravidin resin column. The proteins were eluted from the column using SDS-PAGE buffer and loaded for SDS-PAGE, followed by immunoblotting.

The following antibodies were used: anti-CXCR4 [H-118 and G-19, raised against amino acids $176-293$ and $\mathrm{N}$ terminus, respectively (1: 1000)] and anti-FHC (Y-16) from Santa Cruz Biotechnology (1:500); anti-Akt, anti-phosphoAkt (Ser473), anti-extracellular signal-regulated kinase (ERK), and anti-phosphoERK from Cell Signaling Technology (1:2000); anti- $\beta$-actin from Sigma-Aldrich (1:5000); and anti-pCXCR4S339 antibody (1:50) (Woerner et al., 2005). An image acquisition/analysis system (Alpha Innotech; UN-SCAN IT software from Silk Scientific) was used for detection of chemiluminescent bands and densitometric analysis. Values from actin, Akt, ERK, or CXCR4 bands were used to verify equal protein loading and/or normalization as reported in the test. Data are expressed as percentage of control (mean \pm SE mean).

In vivo morphine treatments and in situ $\left[{ }^{35} S\right]$ GTP $\gamma S$ autoradiography. Animals were treated according to protocols approved by the Drexel University Animal Research Committee. Holtzmann rats in their second postnatal week were used in this study, unless otherwise specified. Morphine sulfate (Sigma-Aldrich) was dissolved in physiological saline and subcutaneously injected in a volume of $1 \mathrm{ml} / \mathrm{kg}$. Rats were killed $30 \mathrm{~min}$, 6,24 , or $48 \mathrm{~h}$, and $5 \mathrm{~d}$ after the administration of morphine $(20 \mathrm{mg} / \mathrm{kg}$, single injection for acute treatment or $10 \mathrm{mg} / \mathrm{kg}$, once a day for $3 \mathrm{~d}$ in the case of long-term treatment). The brain was rapidly removed, quickly frozen, and stored at $-80^{\circ} \mathrm{C}$. The procedure for $\left[{ }^{35} \mathrm{~S}\right] \mathrm{GTP} \gamma \mathrm{S}$ autoradiography was based on established methods as reported previously (Burbassi et al., 2008). Briefly, $20 \mu \mathrm{m}$, frozen coronal sections were cut throughout the hippocampus and thaw mounted onto slides subbed with chromealuminum. Slides were preincubated in slide mailers for $40 \mathrm{~min}$ at $25^{\circ} \mathrm{C}$ in assay buffer (in mM: 50 Tris- $\mathrm{HCl}, 4 \mathrm{MgCl}_{2}, 0.3$ EGTA, and $100 \mathrm{NaCl}$, $\mathrm{pH}$ 7.4), followed by a $20 \mathrm{~min}$ incubation in $2 \mathrm{~mm}$ GDP in assay buffer. Sections were then incubated for $2 \mathrm{~h}$ at $25^{\circ} \mathrm{C}$ in assay buffer containing both $\left[{ }^{35} \mathrm{~S}\right] \mathrm{GTP} \gamma \mathrm{S}(0.04 \mathrm{~nm}, 1250 \mathrm{Ci} / \mathrm{mmol})$ and $2 \mathrm{~mm}$ GDP. Each mailer contained vehicle (basal condition) or $1 \mu \mathrm{M}$ DAMGO (Bachem), $50 \mathrm{~nm}$ CXCL12 (Peprotech), or unlabeled GTP $\gamma S$ (10 mM, to determine nonspecific binding). After incubation, slides were rinsed twice in cold Tris$\mathrm{HCl}(50 \mathrm{~mm}), \mathrm{pH} 7.4$, and then briefly in cold deionized water, dried immediately with a cool stream of air and desiccated, overnight. Slides were apposed to Kodak Biomax MS film (Eastman Kodak) for $48 \mathrm{~h}$. Images from the developed films were scanned and quantified using Image Pro-Plus Version 4.5 software (MediaCybernetics). The percentage increase in $\left[{ }^{35} \mathrm{~S}\right] \mathrm{GTP} \gamma \mathrm{S}$ binding was calculated according to the following formula: $[(S-B) / B \times 100]$, where $B$ is the basal level of $\left[{ }^{35} S\right]$ GTP $\gamma S$ binding, and $S$ is the stimulated level of $\left[{ }^{35} \mathrm{~S}\right] \mathrm{GTP} \gamma \mathrm{S}$ binding.

Reverse transcription-PCR. Total RNA was isolated from frozen brain tissue (cortex) using Trizol Reagent (Invitrogen) and purified using an RNase-Free DNase set purification midi kit (Qiagen). The RNA quality and concentration were assessed using the NanoDrop ND-1000 spectrophotometer (NanoDrop Technologies). Samples with optical density $260 / 280$ and 260/230 ratio of 1.8 or greater were deemed suitable for use in reverse transcription (RT)-PCR studies. RNA was reverse transcribed to CDNA using specific primers for rat CXCR4 (forward, CAT AGA TCT CTC GAG GCC ACC ATG GAG GGG ATC AGT ATA TAC ACT TC; reverse, GGC TCT AGA AAG CTT GCT GGA GTG AAA CTT GAA GAC TCA GAC TC). cDNA was amplified by PCR for 35 cycles. Products were ran on a $1 \%$ agarose gel and visualized under UV light using ethidium bromide. Values from the housekeeping gene aldolase A was used to verify equal mRNA loading.

In vitro and in utero electroporation. In vitro, cortical neurons were transfected using the nucleofector kit from Amaxa Biosystems, as we described previously (Khan et al., 2008), following the protocol of the manufacturer. Briefly, neurons were spun down $(80 \mathrm{rpm})$ and mixed 
with $100 \mu \mathrm{l}$ of nucleofector solution and $1 \mu \mathrm{g}$ of short interfering RNA (siRNA) (Santa Cruz Biotechnology): FHC siRNA-2, which is a pool of three target-specific 20-25 nt siRNAs (sc-72350) or a control siRNA (sc-36869) consisting of a scrambled sequence that will not lead to the specific degradation of any known cellular mRNA (Chellaiah, 2005; Li et al., 2006). The neuron/siRNA mixture was then nucleofected using program G-013. Transfected neurons were then plated at a density of $5 \times 10^{6}$ per $60 \mathrm{~mm}$ culture dish and used on DIV 4 as reported later.

In vivo, downregulation of FHC expression in vivo was achieved by in utero electroporation of plasmids that had been injected into the embryonic ventricles (Saito and Nakatsuji, 2001; Tabata and Nakajima, 2001). In brief, pregnant Holtzmann rats (E16) were used, and expression vectors $(1-2 \mu \mathrm{l})$ were injected into the lateral (left) ventricle of embryonic brains as described previously (Tsai et al., 2005). A pair of copper alloy oval plates that were attached to the electroporation generator (Harvard Apparatus) transmitted five electric pulses at $50 \mathrm{~V}$ for $50 \mathrm{~ms}$ at $1 \mathrm{~s}$ intervals through the uterine wall. Anode was located on the left side of the brain. Pups were used for experiments within $24 \mathrm{~h}$ from birth [postnatal day 0 (P0) to P1]. In agreement with the original protocol (Saito, 2006), under these experimental conditions, transgene delivery, as monitored by green fluorescent protein (GFP) expression (supplemental Fig. $2 \mathrm{~A}$, available at www.jneurosci.org as supplemental material), was primarily localized to neurons in proximity to the injected ventricle, consistent with previous reports (Saito and Nakatsuji, 2001). This pattern of transgene expression allowed the contralateral, nontransfected cortex to serve as the negative control. Two different vectors, both expressing GFP, were used to downregulate FHC expression: either a construct from GenScript targeting the sequence CTTCACAAACTGGCTACTG (sense) of rat FHC mRNA (FHCshRNA/pRNAT-U6.1; $1 \mu \mathrm{g} / \mu \mathrm{l}$ ) or a GIPZ lentiviral shRNAmir from Open Biosystems (clone V2LMM_4175751, National Center for Biotechnology Information, accession number NM_010239; $1 \mu \mathrm{g} / \mu \mathrm{l})$. Both plasmids were tested in cultured neurons before in vivo studies and efficiently inhibit FHC expression (supplemental Fig. 2B) (see Fig. 7). For each set of electroporation, control animals were injected with empty (i.e., no siRNA) vector. Animals were maintained according to protocols approved by the Institutional Animal Care and Use Committee at Columbia University.

Immunohistochemistry. Immunohistochemical analysis was performed as described previously (Shimizu et al., 2007), with minor modifications. Briefly, $20 \mu \mathrm{m}$ rat cortex sections were stored at $-20^{\circ} \mathrm{C}$ for $24 \mathrm{~h}$, air dried at room temperature for $60 \mathrm{~min}$, and then fixed for 1-2 min with acetone at room temperature. Before incubation of primary antibody, nonspecific binding was blocked with normal donkey serum [1:250, diluted with $1 \times$ Tris-buffered saline (TBS), ph 7.4] for $1 \mathrm{~h}$. The sections were then incubated with primary antibody overnight at $4^{\circ} \mathrm{C}$ [anti-FHC (Santa Cruz Biotechnology), 1:50; diluted in $1 \times$ TBS plus $2.5 \%$ normal donkey serum]. After rinsing in $1 \times$ TBS (three times for 5 min), the sections were incubated with HRP anti-goat secondary antibody [(Jackson ImmunoResearch) 1:250, diluted in $1 \times$ TBS plus $2.5 \%$ normal donkey serum; $2 \mathrm{~h}$ at room temperature] and the reaction products were visualized by the avidin-biotin-peroxidase complex method (ABC kit; Vector Laboratories) using 3,3-diaminobenzidine tetrahydrochloride as the chromogen. Negative controls were processed in the same manner but omitting the primary antibody.

cAMP assays. cAMP assays were performed using cAMP-Glo Assay (Promega) following the protocol of the manufacturer (Golla and Seethala, 2002). Briefly, neurons grown on 96-well plates (density of $2 \times 10^{4}$ per well) were treated as indicated in Neurobasal medium containing phosphodiesterase inhibitors IBMX (3-isobutyl-1-methylxanthine) and Ro 20-1724 [4-(3-butoxy-4-methoxybenzyl) imidazoline-2-one] (both from Sigma-Aldrich). The intracellular levels of cAMP were detected using the detection solution provided in the kit after cell lysis. The luminescence was measured using a Victor ${ }^{2}$ TM 1420 Multilabel counter (PerkinElmer Life and Analytical Sciences). A standard curve was performed in parallel for each experiment using serial dilutions of cAMP provided with the kit; data were analyzed with Graph Prism software using a sigmoidal dose-response (variable slope) equation. Changes in cAMP content in brain tissue were measured as reported previously (Yang et al., 2007).
Statistical analysis. Data are reported as mean \pm SEM and total number of experiments. Statistical analysis was performed by one-way ANOVA, followed by Newman-Keuls post hoc test or paired/unpaired Student's $t$ test. $p$ values are reported in legends.

\section{Results}

\section{Morphine down-modulates neuronal CXCR4 function}

We reported previously that stimulation of neuronal CXCR4 by its natural ligand CXCL12 leads to the activation of survival pathways such as ERK and Akt (Patel et al., 2006). Furthermore, pretreatment of neuronal/glia cultures with $\mu \mathrm{OR}$ agonists (i.e., DAMGO or endomorphin) inhibit CXCL12-induced stimulation of these survival pathways in neurons (Patel et al., 2006). However, the above treatments were performed on cortical neurons grown in the presence of a glial feeder layer, whereas glial cells were removed shortly before stimulation of CXCR4 by CXCL12. Because glia cells are direct targets of opioids and release various cytokines and reactive oxygen species in response to these drugs (for review, see Hauser et al., 2007), it is possible that the inhibition of the neuroprotective signaling we observed is a consequence of glial $\mu \mathrm{OR}$ activation. To address this issue and thus establish whether opioid and chemokine receptors may directly interact in neurons, we used a glia-free neuronal culture system for the present study. Furthermore, we also tested the effect of morphine, an active metabolite of the commonly abused opioid heroin and a potent $\mu \mathrm{OR}$ agonist. In agreement with our previous findings, pretreatment of glia-free neurons with the $\mu$ OR-selective agonist DAMGO $(1 \mu \mathrm{M}, 24 \mathrm{~h})$ completely blocked phosphorylation of ERK1/2 and Akt induced by CXCL12 in neurons (Fig. $1 A, C$ ). The effects of DAMGO were abolished by cotreatment with the specific $\mu \mathrm{OR}$ antagonist CTAP (Cys-Tyr-DTrp-Arg-Thr-Pen-Thr- $\mathrm{NH}_{2}$ ) ( $1 \mu \mathrm{M}$; Tocris Bioscience), which by itself did not alter CXCR4 signaling (Fig. $1 B, C$ ). A similar treatment with morphine ( $1 \mu \mathrm{M}$ for $24 \mathrm{~h}$ ) significantly diminished CXCL12-induced phosphorylation of ERK1/2 and Akt in a CTAP-dependent manner (Fig. $1 D-F$ ). Neither agonist affected the stimulation of survival pathways triggered by another chemokine (i.e., CX3CL1) or by the neurotrophic factor BDNF (Patel et al., 2006). Furthermore, this interaction was limited to neuronal cell types because DAMGO did not affect ERK/Akt phosphorylation stimulated by CXCL12 in glial cells (supplemental Fig. 3A, available at www.jneurosci.org as supplemental material). Together, these data suggest a specific crosstalk between endogenous $\mu \mathrm{OR}$ and CXCR4 in neurons and indicate that stimulation of neuronal $\mu \mathrm{OR}$ leads to inhibition of CXCL12-dependent signaling. Furthermore, because the inhibition of CXCR4 is agonist dependent (i.e., CTAP had no effect on CXCR4 signaling), these findings suggest that $\mu \mathrm{OR} / \mathrm{CXCR} 4$ heterodimerization is not involved in the downregulation of the CXCL12 responses reported here, as further discussed later.

The next goal was to examine whether in vivo morphine treatments also resulted in an alteration of CXCL12 responses. To this end, CXCL12-induced G-protein activation was measured in the brain of control and morphine-treated animals by using in situ GTP $\gamma \mathrm{S}$ autoradiography as reported previously (Burbassi et al., 2008). The increase in GTP $\gamma S$ binding caused by CXCL12 in these brain slices is entirely mediated by stimulation of CXCR4 (Burbassi et al., 2008). A first group of animals received a single injection of morphine or saline $(20 \mathrm{mg} / \mathrm{kg}$, s.c.), whereas another group received a daily injection ( $10 \mathrm{mg} / \mathrm{kg}$, s.c.) for 3 consecutive days. Animals were killed after $30 \mathrm{~min}, 6,24$, or $48 \mathrm{~h}$, or $5 \mathrm{~d}$ after the last (or only) morphine injection. Brain slices from all groups of animals were treated with CXCL12 (or vehicle) and processed for GTP $\gamma \mathrm{S}$ autora- 


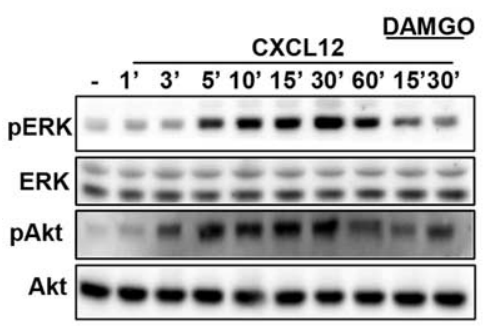

B
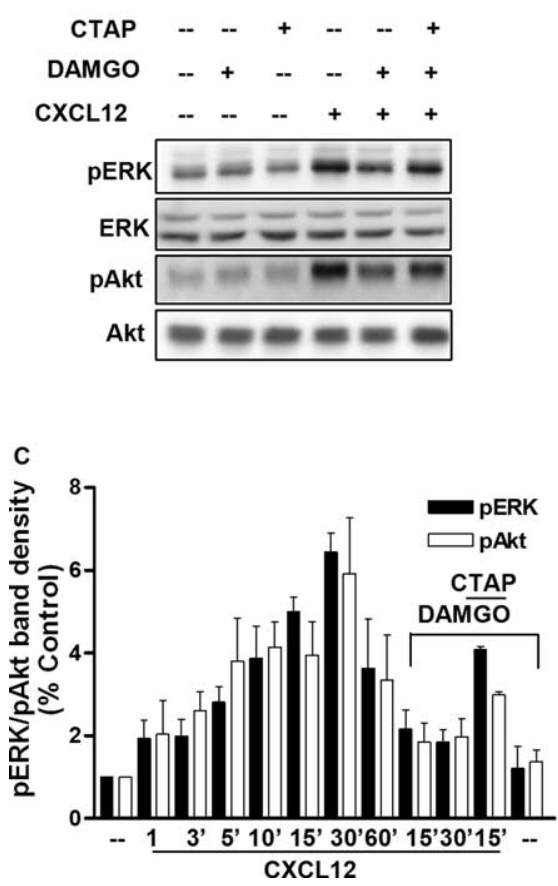

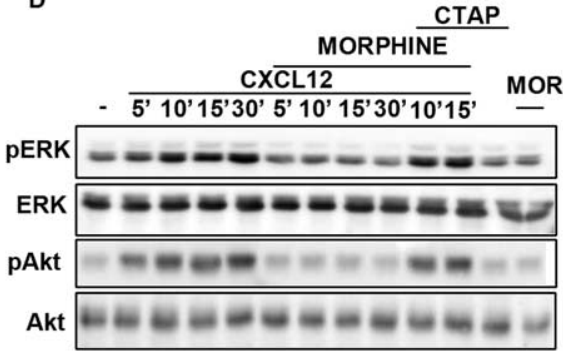

E
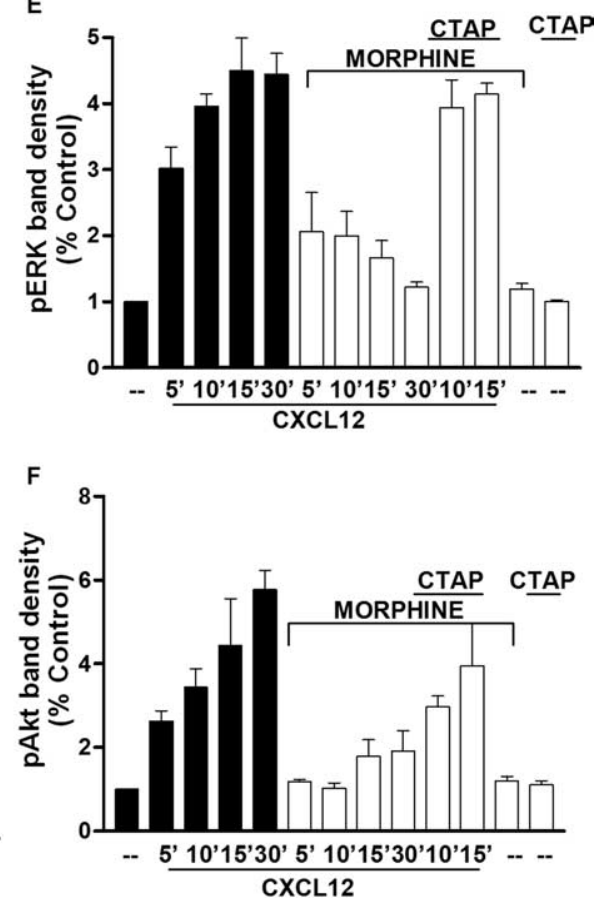

indicating that this extended morphine treatment eventually leads to $\mu \mathrm{OR}$ desensitization as expected (supplemental Fig. 4B, available at www.jneurosci.org as supplemental material) (representative images in Fig. 2E). Experiments that measured tissue levels of cAMP in saline- and morphinetreated animals also suggest receptor uncoupling from $\mathrm{G} \alpha_{\mathrm{i}}$ after long-term treatments. As expected in the case of activation of a $\mathrm{G} \alpha_{\mathrm{i}}$ coupled receptor, a single injection of morphine reduced the overall cAMP content, whereas cAMP levels in the group of animals that received daily injections for $3 \mathrm{~d}$ were similar to controls (data not shown). In line with this, pretreatment of cultured neurons with DAMGO abolished CXCL12 inhibition of cAMP production (supplemental Fig. 5, available at www.jneurosci.org as supplemental material). Considering that CXCR4 associates to $\mathrm{G} \alpha_{\mathrm{i}}$, these data suggest that morphine treatment may compromise the signaling machinery available to CXCR4.

The above actions of opiates, in vivo and in vitro, are not caused by a general reduction in CXCR4 expression. As determined by RT-PCR and Western blots using brain cortex homogenates from morphine (or saline)-treated rats, morphine did not alter total CXCR4 levels in the brain (supplemental Fig. 6, available at www.jneurosci.org as supplemental material). Similarly, DAMGO did not reduce protein levels of CXCR4 in cultured neurons (Patel et al., 2006). Overall, these findings suggest that opioid agonists can alter CXCR4 signaling at very early stages of receptor-G-protein interaction.

1. $\mu 0$ R agonists inhibit CXCL12 signaling in glia-free neuronal cultures. $A$, Effect of $1 \mu M$ DAMGO $(24 \mathrm{~h})$ on ERK phosphorylation induced by CXCL12 (20 nM) in neurons; membranes were stripped and reprobed for total ERK/Akt to confirm equal loading. Cotreatment with the $\mu$ OR (MOR) antagonist CTAP (1 $\mu \mathrm{M})$ abolishes DAMG0 inhibition (B). The bar graphs (C) represent the mean $\pm S E M$ of $p E R K$ or $p A k t$ band densities represented with respect to control levels from five identical independent experiments. The CXCL12 stimulation at 5, 10, 15, and 30 min are all significantly higher than control levels $(p<0.05)$. CXCL12 stimulation at 15 and 30 min after DAMG0 pretreatment is significantly lower than CXCL12 alone $(p<0.05)$. In $D$, neuronal cultures were treated with $1 \mu \mathrm{m}$ morphine (or vehicle) in either the presence or absence of $1 \mu \mathrm{m}$ CTAP for $24 \mathrm{~h}$, followed by $20 \mathrm{~nm} \mathrm{CXCL12} \mathrm{for} \mathrm{5,} \mathrm{10,} \mathrm{15,} \mathrm{or} 30$ min. pERK or pAkt levels were measured by immunoblotting. Total protein levels (ERK/Akt) were probed for loading control. The bar graphs $(\boldsymbol{E}, \boldsymbol{F})$ represent the mean \pm SEM of $p E R K$ or pAkt band densities with respect to control levels from three identical independent experiments. The CXCL12 stimulation at 5, 10, 15, and 30 min are all significantly higher than control levels $(p<0.05)$. Morphine significantly blocks $(p<0.05)$ CXCL12-induced ERK/Akt phosphorylation at all time points.

diography according to the procedure described in Materials and Methods. As shown in Figure 2, a single injection of morphine transiently inhibited CXCL12-induced GTP $\gamma \mathrm{S}$ binding in the brain of treated rats $(A$ and $B)$. This effect was only observed after 6 or $24 \mathrm{~h}$ from the morphine administration and disappeared $2 \mathrm{~d}$ after injection. However, prolonged $(3 \mathrm{~d})$ treatments with morphine induced a steady and longer-lasting downregulation of CXCR4-induced GTP $\gamma \mathrm{S}$ incorporation (Fig. 2C,D); normal CXCR4 function was restored $5 \mathrm{~d}$ after the third injection (supplemental Fig. $4 A$, available at www.jneurosci.org as supplemental material). Morphine inhibition of G-protein activation was observed in different brain areas, including medial and lateral cortex (labeled in the graph as MC and LC, respectively) and the hippocampus (CA1, CA2, and CA3). In these "chronically" treated animals, DAMGO-induced GTP $\gamma \mathrm{S}$ binding was also markedly reduced compared with the saline-treated groups,

\section{Effects of opioids on CXCL12-induced} phosphorylation of neuronal CXCR4 After ligand activation, CXCR4 undergoes phosphorylation at its C-terminus tail, which is involved in protein-protein interaction, such as recruitment of arrestins, and subsequent receptor internalization (Cheng et al., 2000). These events terminate CXCR4-induced G-proteinmediated signaling but stimulate receptor endocytosis and dynamin-dependent Raf-mediated signaling pathways (Sun et al., 2002). Using an antibody that specifically recognizes this ligand-induced CXCR4 phosphorylation (serine 339 residue in human and 338 in rats), we studied the effect of CXCL12 on CXCR4 phosphorylation in neurons treated with opioids. As reported in Figure 3, stimulation of rat cortical neurons with CXCL12 normally causes a time-dependent increase in the phosphorylation of CXCR4 on Ser 338 (here reported as pCXCR4). The effect of CXCL12 on CXCR4 phosphorylation was blocked by the CXCR4 antagonist AMD3100 (1,1'-[1,4phenylenebis(methylene)]bis-1,4,8,11-tetra-azacyclotetradecane octahydrochloride) (100 ng/ml) (Fig. 3A). Control experiments in a human cell line expressing CXCR4 (HOS-X4) confirmed these results (data not shown), which are also in line with our 


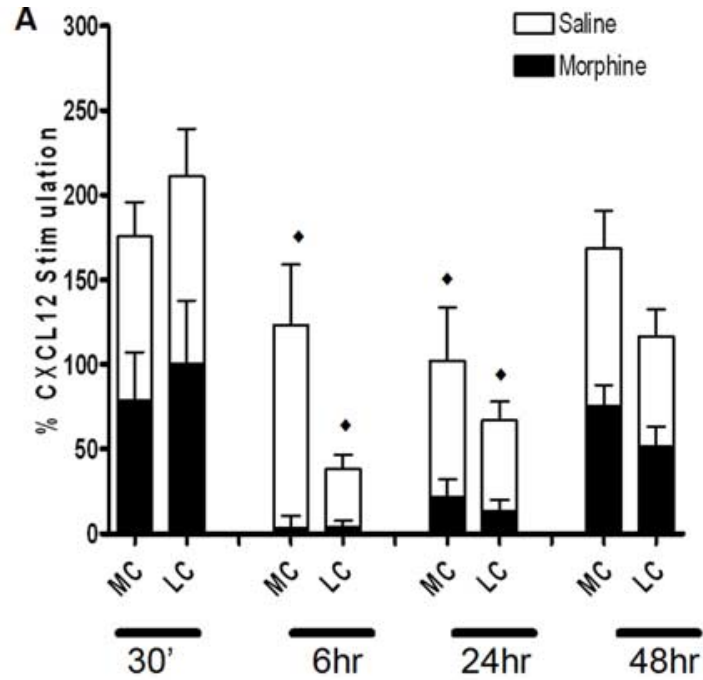

B

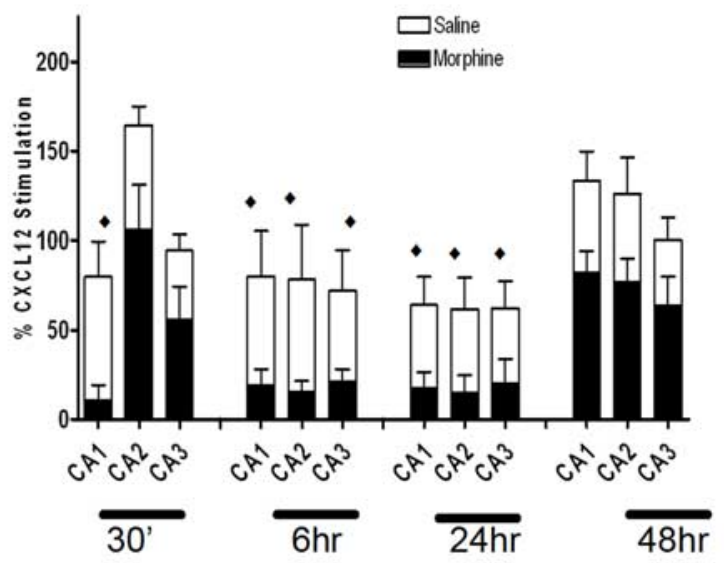

ACUTE
C

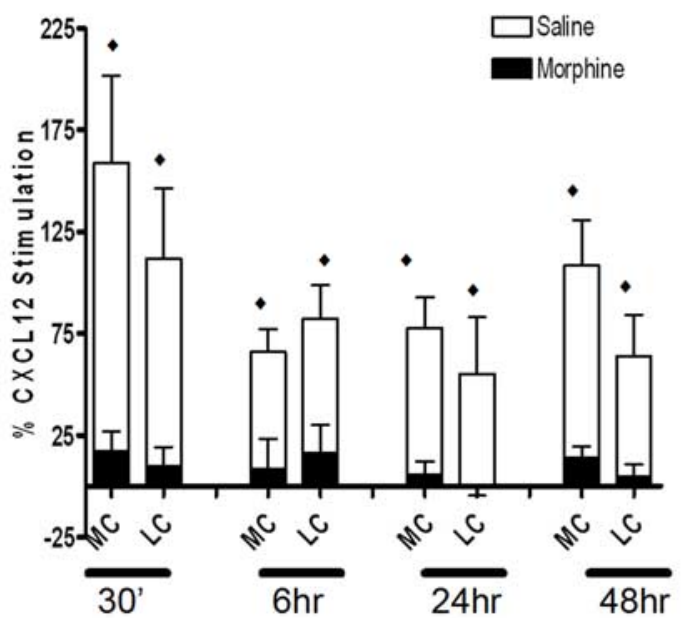

D

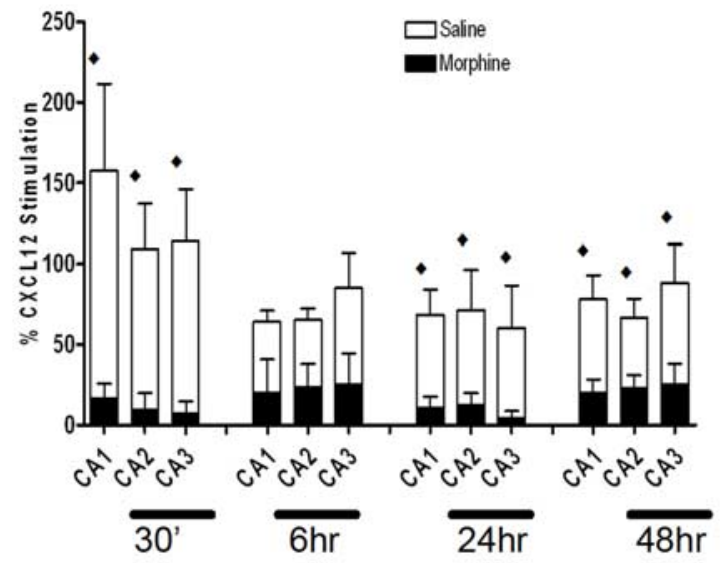

LONG TERM

E
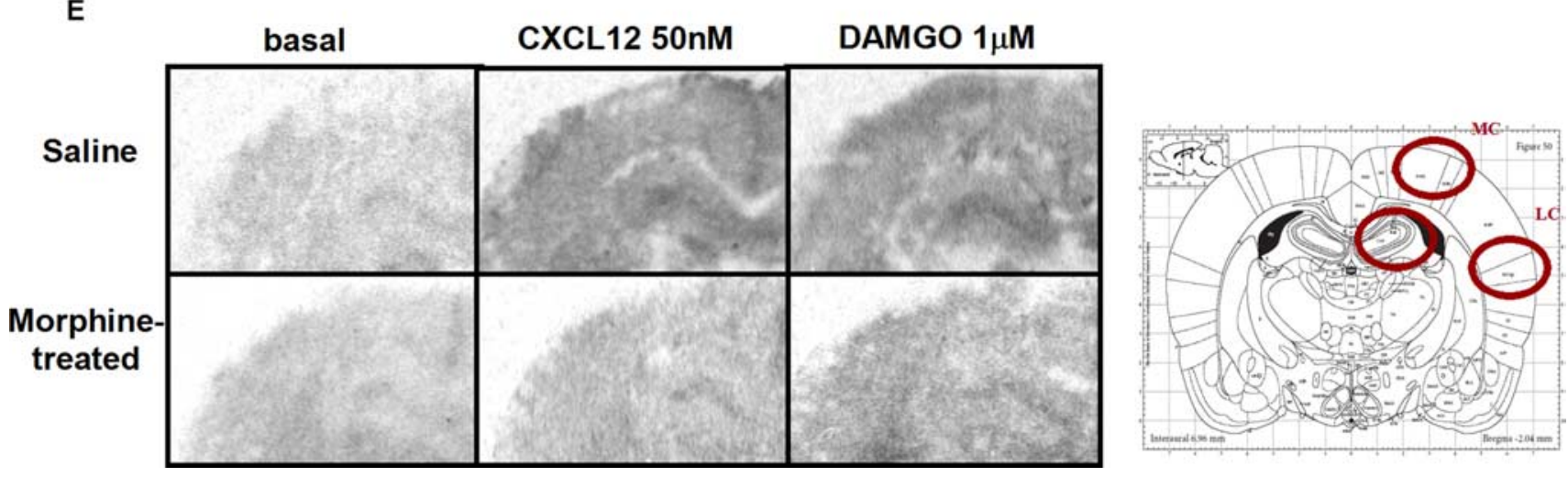

Figure 2. Morphine treatment reduces $C X C L 12$-induced incorporation of $\left[{ }^{35} \mathrm{~S}\right] \mathrm{GTP} \gamma \mathrm{S}$ in the rat brain: pups were treated with saline or morphine acutely (ACUTE; single injection, $20 \mathrm{mg} / \mathrm{kg}$, S.C.; $\boldsymbol{A}, \boldsymbol{B})$ or for an extended time period (LONG-TERM; once a day for $3 \mathrm{~d}, 10 \mathrm{mg} / \mathrm{kg}$, s.c.; $\boldsymbol{C}, \boldsymbol{D})$ and killed after the indicated time. Brain slices were treated with CXCL12 (50 nM) and processed for GTP $\gamma 5$ autoradiography. Representative autoradiograms of GTP $\gamma$ S incorporation after vehicle (left), CXCL12 (middle), and DAMGO (right) stimulation of either saline-treated or morphine-treated pups are reported below the graphs $(\boldsymbol{E})$. Analysis was performed in different brain areas as indicated in the schematic diagram; data from medial and lateral cortex (MC and LC, respectively) are reported in the top graphs; the bottom graphs show data from the hippocampus (distinguished in field CA1, CA2, and CA3). Data are expressed as mean \pm SEM of three animals per experimental group. ( $p<$ 0.01 saline treatment vs morphine treatment for each area reported in graph).

previous studies (Woerner et al., 2005). Neuronal CXCR4 phosphorylation was also blocked by cotreatment with the selective PKC inhibitor Ro 31-8220 (2-[1-(3-(amidinothio)propyl)-1 Hindol-3-yl]-3-(1-methylindol-3-yl)maleimide) (100 nM) (Fig.
$3 B, C)$, in agreement with the reported role of PKC in CXCR4 phosphorylation either direct or mediated by GRK2. Given the importance of receptor phosphorylation in signaling as well as internalization of the receptor, we examined the effects of mor- 

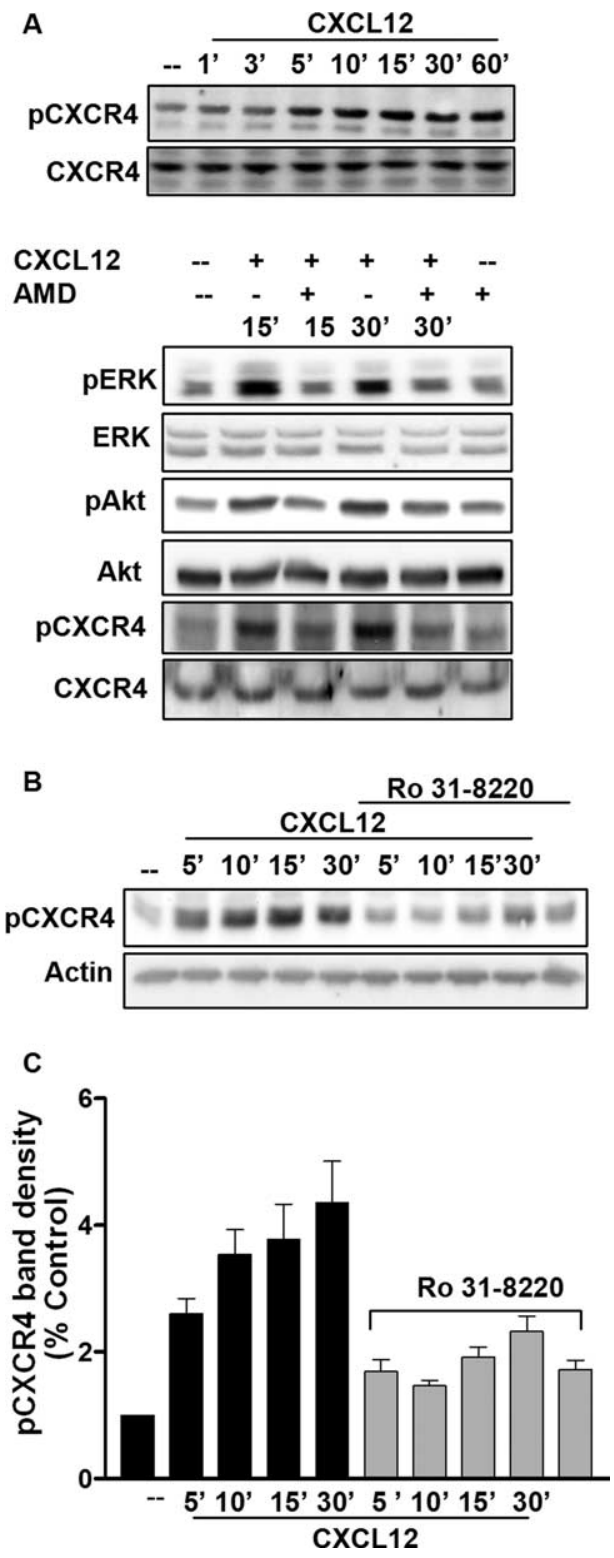

Figure 3. CXCL12 induces a time-dependent phosphorylation of the neuronal CXCR4 C terminus. Cortical neurons were treated with $20 \mathrm{~nm}$ CXCL12 for the indicated time periods. Wholecell lysates were used for immunoblotting using a pERK-, pAkt-, and pCXCR4-specific antibody (Ser338/339). Receptor phosphorylation was blocked by the CXCR4-selective antagonist AMD3100 (100 ng/ml; $\boldsymbol{A}$ ) or by the PKC inhibitor Ro 31-8220 (100 nм; $\boldsymbol{B}$ ). The bar graph represents pCXCR4 band densities (mean \pm SEM) with respect to control levels and after normalization to actin band; $C$ ). (All CXCL12 treatments are significantly higher than control, i.e., $p<0.05$; Ro 31-8220-treated groups are all significantly lower than respective CXCL12 alone, $p<0.05)$.

phine preexposure on CXCL12-induced CXCR4 phosphorylation. Pretreatment with morphine $(1 \mu \mathrm{M}, 24 \mathrm{~h})$ completely abolished receptor phosphorylation induced by CXCL12 at all measured time points ( 5 to $30 \mathrm{~min}$ ) (Fig. $4 A, D$ ). Morphine effect was reversed by CTAP underlying the need for $\mu \mathrm{OR}$ stimulation in the mechanism leading to CXCR4 inhibition (Fig. 4A,D). This was further confirmed by similar experiments with DAMGO, which also inhibited CXCL12-induced CXCR4 phosphorylation (Fig. $4 B, D$ ). These results suggest that opioids may alter neuronal CXCR4 signaling by interfering with receptor activation, internalization, and recycling. To test this possibility, we isolated plasma membrane proteins by means of cell surface protein bi-

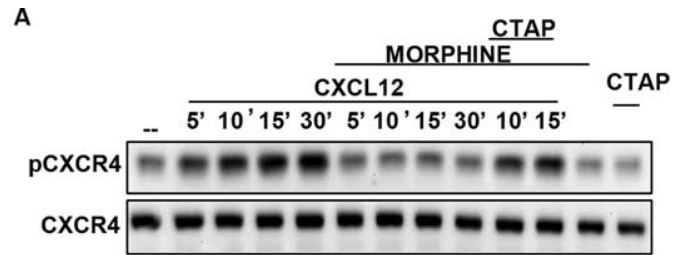

B

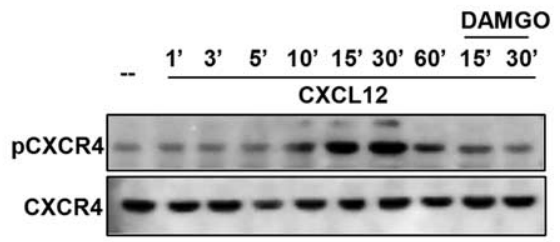

C
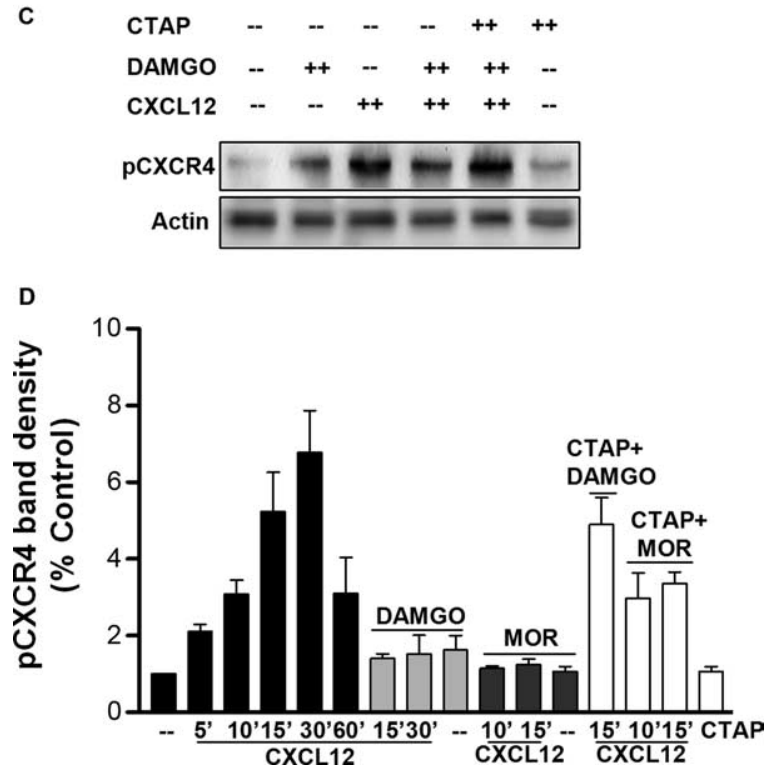

Figure 4. $\quad \mu O R$ agonists inhibit CXCL12-induced phosphorylation of CXCR4. Glia-free neuronal cultures were treated with $1 \mu \mathrm{m}$ morphine (or vehicle) or DAMGO for $24 \mathrm{~h}$, followed by $20 \mathrm{~nm}$ CXCL12 for indicated amounts of time. Both agonists markedly reduce levels of $p C X C R 4$ in total cellular extracts, and CTAP $(1 \mu \mathrm{m})$ reversed this effect $(\boldsymbol{A}-\boldsymbol{C})$. The bar graphs $(\boldsymbol{D})$ represent the mean \pm SEM of $p C X C R 4$ band densities represented with respect to control levels from three independent identical experiments [all CXCL12 treatments are significantly higher than control, i.e., $p<0.05$ or less; $\mathrm{DAMGO}$ or $\mu 0 \mathrm{R}$ (MOR)-treated groups are all significantly lower than corresponding CXCL12 alone, $p<0.05$ or less].

otinylation and measured the levels of surface CXCR4 and pCXCR4 in neurons treated with CXCL12 and/or DAMGO. The data reported in Figure $5 A$ show that, although DAMGO treatment by itself did not change CXCR4/pCXCR4 protein levels, it prevented the reduction of surface CXCR4 that normally follows ligand stimulation of the receptor. This can result from reduced internalization or faster recycling of the receptor. However, the fraction of CXCR4 remaining on the membrane in DAMGOtreated neurons appears to be still phosphorylated on Ser339 (CXCR4/pCXCR4 densitometry ratios are as follows: untreated group: control, $0.95 ; 5 \mathrm{~min}, 0.73 ; 15 \mathrm{~min}, 0.81 ; 60 \mathrm{~min}, 1.67$; DAMGO-treated group: control, 0.90; 5 min, 0.96; 15 min, 0.80; $60 \mathrm{~min}, 0.75$ ), suggesting that DAMGO primarily inhibited CXCL12-induced internalization. Therefore, opioid pretreatment may delay CXCR4 recycling, which would lead to signaling deficits.

To further investigate the mechanism involved in the opioid inhibition of CXCR4 signaling, we sought to determine whether prolonged exposure to the $\mu \mathrm{OR}$ agonists was necessary to down- 
regulate CXCR4-mediated responses. Therefore, neurons were pretreated with DAMGO for relatively short times ( $15 \mathrm{~min}$ to $3 \mathrm{~h}$ ) and then exposed to CXCL12 for 15 min (Fig. 5B) or cotreated with DAMGO plus CXCL12 for 5 min (data not shown). These experiments showed that acute DAMGO treatments do not affect CXCL12-induced responses. Additional studies on neurons treated with DAMGO for $3,6,18$, or $24 \mathrm{~h}$ revealed that several hours (i.e., >6) in the continuous presence of DAMGO were indeed necessary to downregulate CXCR4 function (Fig. 5C). Moreover, cotreatment with the protein synthesis inhibitor cycloheximide (CHX) $(1 \mu \mathrm{g} / \mathrm{ml})$ prevented the effect of DAMGO on CXCR4 signaling (Fig. 5D). Overall, these findings suggest that opioid treatment induces long-term adaptations in neurons that require de novo protein synthesis and result in deficits of CXCR4 signaling. As mentioned previously, opioid treatment did not affect CXCR4 protein levels in neurons (supplemental Fig. 6, available at www.jneurosci.org as supplemental material) (Patel et al., 2006).

\section{FHC is involved in regulation of neuronal CXCR4 by $\mu \mathrm{OR}$}

FHC is a novel intracellular regulator of CXCR4, which has been shown to inhibit CXCR4 signaling in different cell lines, namely HEK 293 cells, HeLa cells, and Jurkat cells (Li et al., 2006). These studies demonstrated that stimulation with CXCL12 induced the association of CXCR4 with FHC and subsequent inhibition of CXCR4 signaling. Interestingly, the C-terminus domain of CXCR4 is involved in the FHC/CXCR4 association, suggesting that FHC may be involved in CXCR4 trafficking. Furthermore, they show that overexpression of FHC leads to downregulation of CXCR4-induced chemotaxis and signaling (i.e., MAPK activation), whereas FHC silencing has the opposite effects.

Based on these findings, we hypothesized that opioids increase the neuronal levels of FHC, thus inhibiting CXCR4 signaling. Hence, we studied the effect of DAMGO and morphine on FHC protein levels in the cortical neurons. Both DAMGO and morphine cause a time-dependent increase in neuronal FHC levels, and this effect is blocked by CTAP (Fig. 6A-D). Furthermore, an increase in the FHC protein was also reported in the cortex of morphine-treated animals (Fig. 6E). In addition, treatment of neuronal cultures with $\mathrm{CHX}$ blocked the upregulation of FHC induced by DAMGO (Fig. 6G,H). These data further support the hypothesis that de novo protein synthesis is required to attain CXCR4 inhibition by opioids. The effect of opioids on FHC protein levels is cell type specific because DAMGO treatment did not cause any changes in FHC in rat primary glial cells (supplemental Fig. 3A, available at www.jneurosci.org as supplemental material), which is consistent with the lack of effect of DAMGO or morphine on CXCR4 signaling in glia. Immunoprecipitation experiments (using the Exactacruz kit from Santa Cruz Biotechnology) in cultured neurons showed that FHC coprecipitated with CXCR4 (Fig. 6F); DAMGO pretreatment enhanced the amount of FHC that associated with neuronal CXCR4 (Fig. 6 F). Remarkably, changes in FHC protein levels induced by morphine or DAMGO in vivo or in vitro (Fig. 6) temporally correlated with the alterations of CXCR4 function described previously (Figs. 2, $5 B, C)$. In particular, the onset and decay of FHC upregulation inversely correlate with CXCR4 activation. For instance, only when the CXCR4 function is completely restored, i.e., $5 \mathrm{~d}$ after the last injection, FHC levels return back to normal in the brain of long-term-treated animals (supplemental Fig. 4C, available at www.jneurosci.org as supplemental material). In summary, these results point to a crucial role of FHC in mediating the effect of opioids on neuronal CXCR4. To test this hypothesis, expression
A

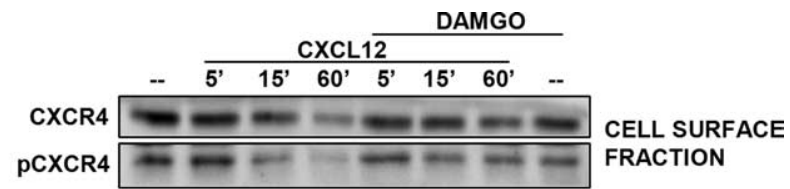

B

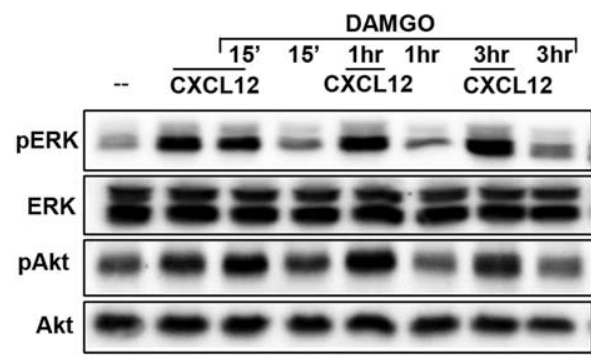

C

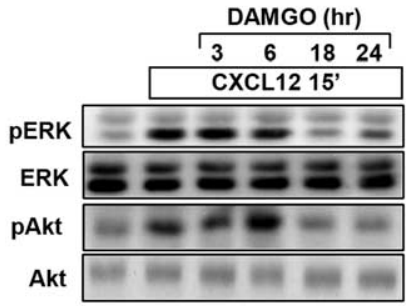

D

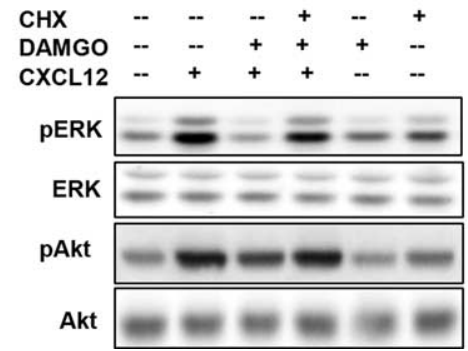

Figure 5. DAMG0 inhibits ligand-induced $C X C R 4$ internalization. Plasma membrane proteins from neurons treated with DAMGO $(1 \mu \mathrm{m}, 24 \mathrm{~h})$ or vehicle, followed by CXCL12 stimulation, were used for the CXCR4 and pCXCR4 immunoblots reported in $A$, whereas experiments with total extracts are reported in other panels. Data shown in $\boldsymbol{B}$ and $\boldsymbol{C}$ are from neuronal cultures treated with DAMGO for 15 min or 1,3, 6, 18, or $24 \mathrm{~h}$ as indicated, followed by acute CXCL12 stimulation (20 nм; 15 min). Additional experiments (D) were performed with neurons incubated with DAMGO $(1 \mu \mathrm{m} ; 24 \mathrm{~h})$ in the presence or absence of CHX $(1 \mu \mathrm{g} / \mathrm{ml})$, followed by acute CXCL12 treatment (20 nm; $15 \mathrm{~min})$.

of FHC in neurons was inhibited using a pool of three targetspecific 20-25 nt siRNAs designed to block FHC gene expression; as described in Materials and Methods, a control siRNA was used to determine the specificity of action. Knockdown of FHC was confirmed by Western blotting, which shows a considerable reduction $(>70 \%)$ in FHC protein levels in the siRNA-transfected neurons compared with control (Fig. 7A). Neurons transfected with FHC siRNA (or control siRNA) were then treated with DAMGO (or vehicle) for $24 \mathrm{~h}$, followed by CXCL12 stimulation. As expected, DAMGO pretreatment blocked the phosphorylation of ERK/Akt induced by CXCL12 in the control cells (Fig. $7 B)$. However, in the FHC-deficient cells, DAMGO pretreatment did not affect CXCL12-stimulated ERK/Akt phosphorylation (Fig. 7B). Furthermore, CXCL12 stimulation was enhanced in these neurons, in agreement with previous studies ( $\mathrm{Li}$ et al., 2006). Overall, these data provide compelling evidence that the upregulation of FHC levels is a key factor in the inhibition of CXCR4 signaling by opioids. This conclusion is fully supported by the aforementioned in vivo studies showing that morphine 
A

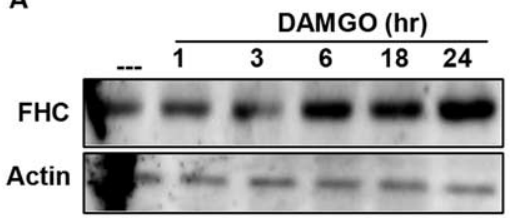

B
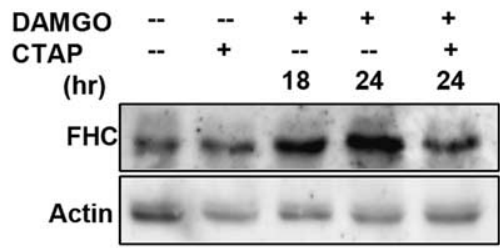

C

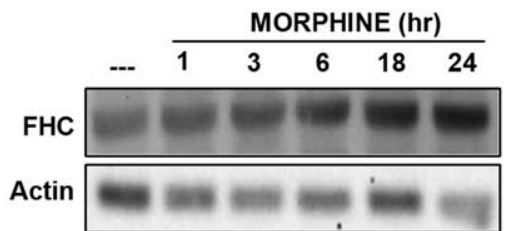

D

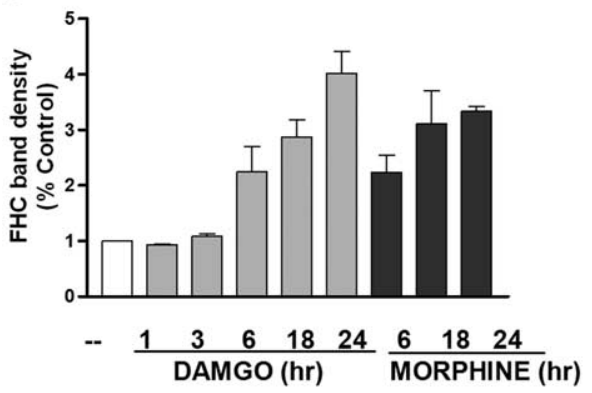

$\mathrm{E}$

G
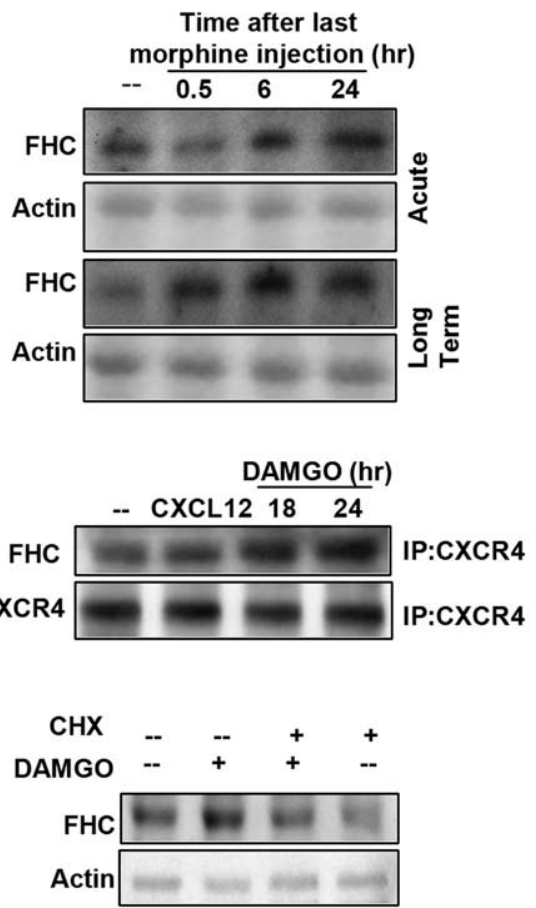

H

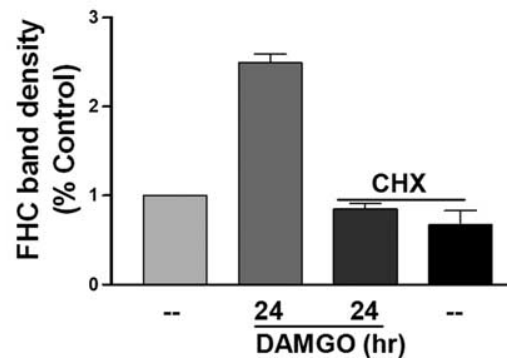

Figure 6. Opioids upregulate $F H C$ protein levels in cortical neurons and brain homogenates. Cortical neurons were treated with $1 \mu \mathrm{M} \operatorname{DAMGO}(\boldsymbol{A}, \boldsymbol{B})$ or morphine $(\boldsymbol{C})$ for indicated time periods. Whole-cell extracts were run on a $10 \%$ SDS-PAGE, followed by immunoblotting using a FHC-specific antibody (see also supplemental Fig. $3 B$, available at www.jneurosci.org as supplemental material). $\boldsymbol{B}$, The involvement of $\mu$ OR was confirmed by using (TAP $(1 \mu \mathrm{M})$. $\boldsymbol{D}$, The bar graph shows FHC band density (mean \pm SEM) represented with respect to control; DAMG0 or morphine treated (6 to $24 \mathrm{~h}$ ) are all significantly higher than control ( $p<$ 0.05). E, Cortical tissue homogenates were prepared from control or morphine-treated rats as described in Materials and Methods.

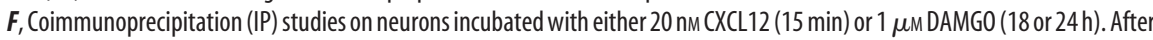
blotting for $F H C$, membrane was stripped and reprobed for CXCR4. G, Neurons were treated with DAMGO and/or CHX for $24 \mathrm{~h}$, and whole-cell extracts were immunoblotted for FHC. Membranes were stripped and reprobed for actin to confirm equal loading. $\boldsymbol{H}$, The bar graph represents FHC band densities (mean \pm SEM) represented with respect to control levels (DAMGO plus CHX group is significantly lower than DAMG0 alone; $p<0.05)$.

stimulates FHC in the brain of treated animals (Fig. 6) and that changes in FHC correspond to alterations in the functional effect of morphine (Figs. 2, 5B,C) (supplemental Fig. 4, available at www.jneurosci.org as supplemental material). Interestingly, ongoing studies in our laboratory also show that FHC levels in the brain of $\mu \mathrm{OR}$ knock-out mice are significantly lower than in wild-type littermate (S. Burbassi, R. Sengupta, and O. Meucci, unpublished observations), which further indicates $\mu \mathrm{OR}$ control of FHC in vivo. However, to further demonstrate the potential relevance of the $\mu \mathrm{OR} / \mathrm{FHC/CXCR} 4$ pathway in vivo, we tested coupling of CXCR4 to G-protein in brain of FHC-deficient animals treated with morphine. To this end, in utero electroporation was used to downregulate FHC expression in vivo by short hairpin RNA (shRNA). This approach provides a powerful means for efficient and long-lasting expression of transgenes in neuronal cells in selected brain areas (Saito and Nakatsuji, 2001; Tabata and Nakajima, 2001). Although previous reports indicate that this methodology produces transgene for several weeks (Saito, 2006; Navarro-Quiroga et al., 2007); in the present studies, GTP autoradiography was performed within 5-6 d of electroporation to limit spreading of transfected cells, which would have reduced the spatial resolution of the autoradiography studies. Therefore, as described in detail in Materials and Methods, animals were electroporated in utero at E16, treated with morphine $(20 \mathrm{mg} / \mathrm{kg}$, s.c.) shortly after birth (P0-P1), and killed $\sim 6-8 \mathrm{~h}$ after morphine (or saline) injection. CXCR4 coupling to heterotrimeric G-protein was determined as described previously by GTP $\gamma S$ incorporation in both the transfected part of the brain (left cortex) and the opposite hemisphere in either saline- or morphine-treated animals (Fig. 7C-E). Two different shRNA constructs, targeting different sequences of the FHC mRNA (see Materials and Methods), were used for in vivo silencing; efficient downregulation of FHC was assessed by Western blot and immunohistochemistry studies (Fig. 7C,D) (supplemental Fig. 2, available at www.jneurosci.org as supplemental material). The results show that morphine effect on CXCR4 signaling was markedly reduced in the FHC-deficient areas, consistent with the diminished FHC expression, whereas the effect of morphine on CXCR4 was still clearly visible in the opposite cortex, which was comparable with that observed in control animals (Fig. 7E). These findings indicate that FHC plays a major role in opioid-mediated inhibition of CXCR4 both in vitro and in vivo.

\section{Discussion}

The mechanisms involved in the regulation of GPCRs, such as the chemokine receptor CXCR4, are generally complex and include both homologous and heterologous regulation (Marchese et al., 2003; Busillo and Benovic, 2007). Although the receptor regulation after stimulation by its cognate ligand is overall quite well characterized, the mechanisms leading to heterologous desensitization are less clearly defined. However, this process has a significant impact on both normal and pathological receptor function and can also be exploited for therapeutic purposes. Several studies indicate that opioid agonists are important modulators of chemokine receptors, and different mechanisms have been proposed, including downregulation of chemokine receptors, signaling crosstalk, and receptor heterodimerization (Steele et al., 2003; Chen et al., 2004; Finley et al., 2008; Pello et al., 2008). However, in many instances, conclusions are based on studies of recombinant expression systems that may differ greatly from the native 
systems because of the (nonphysiologic) expression levels of recombinant receptors and/or to difference in the signaling machinery available in various types of cells. Therefore, we focused on the interaction between $\mu \mathrm{OR}$ and CXCR4 constitutively expressed in cortical neurons and the mechanisms responsible for the inhibition of CXCR4 signaling by morphine. This study presents the first evidence of a crosstalk between endogenous CXCR4 and $\mu \mathrm{OR}$ in neurons that affects their survival and therefore may be implicated in neuropathology, particularly neuroAIDS, in the context of drug abuse. It also provides the first demonstration that $\mu \mathrm{ORs}$ regulate the expression of FHC in neurons, thus controlling an important and novel intracellular modulator of neuronal CXCR4 signaling. Finally, these results also unravel an unprecedented mechanism of GPCR heterologous regulation. The data suggest that upregulation of FHC by $\mu \mathrm{OR}$ activation promotes the association of FHC with CXCR4 interfering with coupling of this receptor to specific G-proteins, its phosphorylation (and likely intracellular trafficking), and downstream signaling events. Given the timeframe of the observed effects, the results of the CHX experiments, and the lack of CXCR4 inhibition by the $\mu \mathrm{OR}$ antagonist CTAP, it seems unlikely that the impairment in CXCR4 function is related to $\mu \mathrm{OR} / \mathrm{CXCR} 4$ heterodimerization, an event reported previously in other cells (Toth et al., 2004). This is in line with studies in immune cells in which a relatively short (i.e., minutes) exposure to $\mu \mathrm{OR}$ agonists does not alter CXCR4 function, although it inhibits CCR5-induced cellular responses (Szabo et al., 2003). However, it is possible that prolonged morphine/ DAMGO treatments promotes interaction of CXCR4 with other opioid receptors (i.e., $\kappa$ or $\delta$ ) that may in turn inhibit normal function of CXCR4 (Finley et al., 2008; Pello et al., 2008). Although these hypotheses are currently been investigated, the results of the present study suggest that overstimulation of $\mu \mathrm{OR}$ affects CXCR4 resensitization/recycling mechanisms and negatively regulate downstream signaling in neurons. Considering that both DAMGO and morphine induce such alterations, the inhibition of CXCR4 appears to be independent of tolerance mechanisms, but this remains to be ascertained.

Overall changes in CXCR4 protein levels in DAMGO-treated neurons were excluded by the present and previous (Patel et al., 2006) studies. Therefore, CXCR4 would still be available for binding to the HIV envelope protein, in line with other reports showing increased gp120 neurotoxicity in cultures of neuronal progenitors treated with morphine (Hu et al., 2005) and with
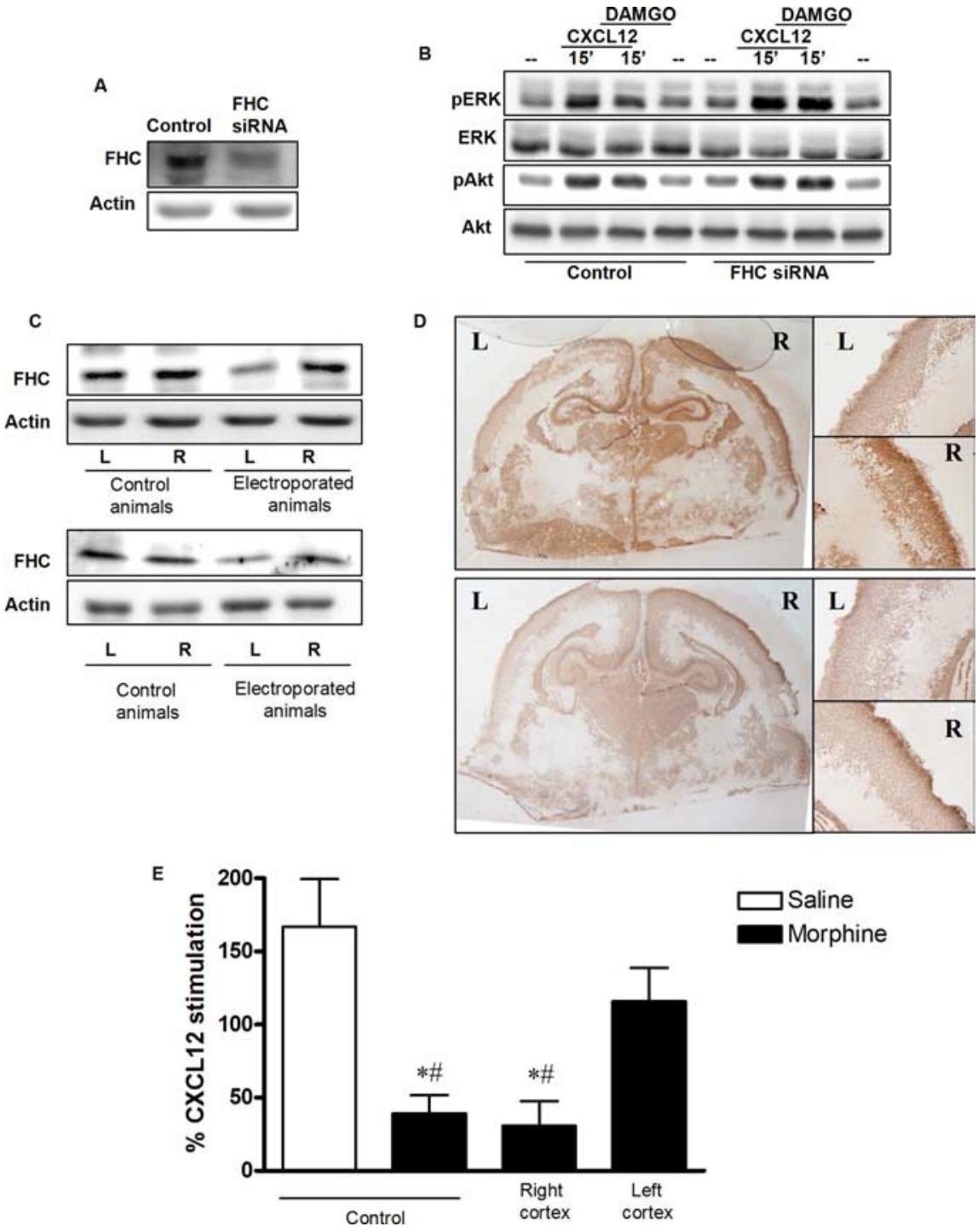

Figure 7. Involvement of FHC in the inhibitory effects of opioids on CXCR4 signaling. $\boldsymbol{A}$, Protein level of FHC are reduced in neurons transfected with FHC siRNAs as determined by immunoblot. Control neurons are transfected with a scrambled siRNA. $\boldsymbol{B}$, Effect of $1 \mu \mathrm{M}$ DAMGO on CXCL12-induced ERK/Akt phosphorylation was determined in control or FHC siRNA transfected neurons using phosphospecific antibodies and Western blot. Membranes were stripped and reprobed for total proteins to confirm equal loading. C, Protein levels of FHC are reduced in brain areas expressing FHC shRNA as reported in detail in Materials and Methods. Top blots: GenScript shRNA plasmid; bottom blots: Open Biosystem shRNA plasmid. L, Left cortex (i.e., transfected side); R, right cortex. Quantification of the band densities revealed 76\% reduction in FHC tissue levels in the left hemispheres (see also supplemental Fig. 2D, available at www.jneurosci.org as supplemental material). Membranes were stripped and reprobed for actin to confirm equal loading. D, Representative pictures of FHC immunostaining in cortical brain sections of electroporated pups ( $6 \mathrm{~d}$ after transfection, GenScript plasmid). E, Pups (P0 -P1) were treated with saline or morphine acutely (single injection, $20 \mathrm{mg} / \mathrm{kg}$, s.c.) and killed within $24 \mathrm{~h}$. Brain slices were treated with CXCL12 $(50 \mathrm{~nm})$ and processed for GTP $\gamma S$ autoradiography. Analysis was performed in the cortex (medial and lateral cortex), distinguishing between left and right side in the case of electroporated animals. In controls, no differences have been noticed between left and right areas of the brain (data not shown). Data are expressed as mean \pm SEM of five animals per experimental group ( ${ }^{\#} p<0.01$ vs saline; ${ }^{*} p<0.01$ vs left cortex).

other HIV infection studies. This may represent an additional factor increasing neuronal vulnerability in HIV-infected drug users. Thus, morphine can contribute to HIV neurotoxicity by both preventing the neuroprotective function of CXCR4/CXCL12 and promoting gp120-induced damage. In this regard, it should be noted that our previous studies show that DAMGO does not impair the ability of gp120 to mobilize intracellular calcium in neuronal cultures (J. P. Patel and O. Meucci, unpublished observations) and that alterations of calcium homeostasis represent an important mechanism of gp120 neurotoxicity (for review, see 
Kaul and Lipton, 2006). Furthermore, overexpression of FHC in cell lines does not reduce CXCR4-induced intracellular calcium increase ( $\mathrm{Li}$ et al., 2006). The apparent discrepancy between the effect of DAMGO on CXCR4-induced $\mathrm{Ca}^{2+}$ response and the regulation of other G-protein-mediated pathways may be attributable to the ability of long-term DAMGO treatment to induce/ promote coupling of CXCR4 to $\mathrm{G}_{\mathrm{q}}$ rather than $\mathrm{G} \alpha_{\mathrm{i} / \mathrm{o}}$. Because the GTP $\gamma \mathrm{S}$ incorporation assay is primarily an indication of $\mathrm{G} \alpha_{\mathrm{i} / \mathrm{o}}$ activation, our data would support this hypothesis, which is also in agreement with the opposite outcome of CXCR4 stimulation on neuronal survival during CXCL12 or gp120 binding (Meucci et al., 1998; Chalasani et al., 2003; Khan et al., 2004, 2005), as well as the reported effects of morphine on gp120 neurotoxicity ( $\mathrm{Hu}$ et al., 2005). Furthermore, previous studies have reported that gp120-induced signaling is often insensitive to pertussis toxin inhibition (Del Corno et al., 2001), indicating the possible involvement of $\mathrm{G}_{\mathrm{q}}$.

Overall, our findings show that opiates such as morphine inhibit neuronal CXCR4 signaling both in vitro and in vivo: this inhibitory effect is cell autonomous (i.e., not mediated by glia), involves posttranslational modifications of the receptor (rather than changes in expression levels), and is mediated by upregulation of FHC. This study is of particular clinical relevance considering that ferritin is a widespread ubiquitous protein, whose expression can be directly and indirectly regulated by iron supply (Li et al., 2006; Sammarco et al., 2008); FHC can also be secreted by cells and act as immunosuppressor (Gray et al., 2001). Interestingly, serum ferritin levels are significantly higher in male opiate addicts than in control groups (Verde Méndez et al., 2003), and increased levels of ferritin were also found recently in the CSF of HIV patients presenting with acute neurological episodes (Phuapradit et al., 1996; Deisenhammer et al., 1997). In agreement with these reports, ongoing immunohistochemistry studies in our laboratory indicate that FHC protein levels are upregulated in postmortem brain tissue obtained from HIV patients affected by neurological deficits (Memorial-Sloan-Kettering score 2), which also showed alterations of CXCR4 phosphorylation (our unpublished data; initial studies presented at the 2008 Annual Meeting of the Society for Neuroscience). Moreover, emerging evidence highlight the role of ferritin (mainly FHC) in inflammation and oxidative stress, which both lead to neuronal injury, as well as in other neurologic disorders (Pham et al., 2004; Sultana et al., 2007). For instance, iron and FHC deficits in the brain appear to be instrumental in restless leg syndrome and loss of dopaminergic neurotransmission, whereas upregulation of FHC has been reported in Alzheimer's patients (Kondo et al., 1996; Clardy et al., 2006). Interestingly, FHC null animals die in utero and heterozygous mice show indices of oxidative stress and apoptosis in the brain (Thompson et al., 2003). This indicates that ferritin is involved in both physiological and pathological processes. Therefore, additional studies on the mechanisms and implications of FHC regulation by opioids and its consequence on neuronal function during development and adult life may offer valid and novel therapeutic approaches for multiple neurodegenerative disorders.

\section{References}

Aung W, Hasegawa S, Furukawa T, Saga T (2007) Potential role of ferritin heavy chain in oxidative stress and apoptosis in human mesothelial and mesothelioma cells: implications for asbestos-induced oncogenesis. Carcinogenesis 28:2047-2052.

Bardi G, Sengupta R, Khan MZ, Patel JP, Meucci O (2006) Human immunodeficiency virus gp120-induced apoptosis of human neuroblastoma cells in the absence of CXCR4 internalization. J Neurovirol 12:211-218.
Berger EA, Murphy PM, Farber JM (1999) Chemokine receptors as HIV-1 coreceptors: roles in viral entry, tropism, and disease. Annu Rev Immunol 17:657-700.

Bresgen N, Ohlenschläger I, Fiedler B, Wacht N, Zach S, Dunkelmann B, Arosio P, Kuffner E, Lottspeich F, Eckl PM (2007) Ferritin: a mediator of apoptosis? J Cell Physiol 212:157-164.

Brewer GJ (1997) Isolation and culture of adult rat hippocampal neurons. J Neurosci Methods 71:143-155.

Brewer GJ, Torricelli JR, Evege EK, Price PJ (1993) Optimized survival of hippocampal neurons in B27-supplemented Neurobasal, a new serumfree medium combination. J Neurosci Res 35:567-576.

Burbassi S, Aloyo VJ, Simansky KJ, Meucci O (2008) GTPgammaS incorporation in the rat brain: a study on mu-opioid receptors and CXCR4. J Neuroimmune Pharmacol 3:26-34.

Busillo JM, Benovic JL (2007) Regulation of CXCR4 signaling. Biochim Biophys Acta 1768:952-963.

Chalasani SH, Baribaud F, Coughlan CM, Sunshine MJ, Lee VM, Doms RW, Littman DR, Raper JA (2003) The chemokine stromal cell-derived factor-1 promotes the survival of embryonic retinal ganglion cells. J Neurosci 23:4601-4612.

Chellaiah MA (2005) Regulation of actin ring formation by rho GTPases in osteoclasts. J Biol Chem 280:32930-32943.

Chen C, Li J, Bot G, Szabo I, Rogers TJ, Liu-Chen LY (2004) Heterodimerization and cross-desensitization between the mu-opioid receptor and the chemokine CCR5 receptor. Eur J Pharmacol 483:175-186.

Cheng ZJ, Zhao J, Sun Y, Hu W, Wu YL, Cen B, Wu GX, Pei G (2000) beta-arrestin differentially regulates the chemokine receptor CXCR4mediated signaling and receptor internalization, and this implicates multiple interaction sites between beta-arrestin and CXCR4. J Biol Chem 275:2479-2485.

Clardy SL, Earley CJ, Allen RP, Beard JL, Connor JR (2006) Ferritin subunits in CSF are decreased in restless legs syndrome. J Lab Clin Med 147:67-73.

Deisenhammer F, Miller RF, Brink NS, Harrison MJ, Thompson EJ (1997) Cerebrospinal fluid ferritin in HIV infected patients with acute neurological episodes. Genitourin Med 73:181-183.

Del Corno M, Liu QH, Schols D, de Clercq E, Gessani S, Freedman BD, Collman RG (2001) HIV-1 gp120 and chemokine activation of Pyk2 and mitogen-activated protein kinases in primary macrophages mediated by calcium-dependent, pertussis toxin-insensitive chemokine receptor signaling. Blood 98:2909-2916.

Doranz BJ, Orsini MJ, Turner JD, Hoffman TL, Berson JF, Hoxie JA, Peiper SC, Brass LF, Doms RW (1999) Identification of CXCR4 domains that support coreceptor and chemokine receptor functions. J Virol 73:2752-2761.

Feng Y, Broder CC, Kennedy PE, Berger EA (1996) HIV-1 entry cofactor: functional cDNA cloning of a seven-transmembrane, $G$ protein-coupled receptor. Science 272:872-877.

Finley MJ, Chen X, Bardi G, Davey P, Geller EB, Zhang L, Adler MW, Rogers TJ (2008) Bi-directional heterologous desensitization between the major HIV-1 co-receptor CXCR4 and the kappa-opioid receptor. J Neuroimmunol 197:114-123.

Floridi F, Trettel F, Di Bartolomeo S, Ciotti MT, Limatola C (2003) Signalling pathways involved in the chemotactic activity of CXCL12 in cultured rat cerebellar neurons and CHP100 neuroepithelioma cells. J Neuroimmunol 135:38-46.

Golla R, Seethala R (2002) A homogeneous enzyme fragment complementation cyclic AMP screen for GPCR agonists. J Biomol Screen 7:515-525.

Gray CP, Franco AV, Arosio P, Hersey P (2001) Immunosuppressive effects of melanoma-derived heavy-chain ferritin are dependent on stimulation of IL-10 production. Int J Cancer 92:843-850.

Grimm MC, Ben-Baruch A, Taub DD, Howard OM, Resau JH, Wang JM, Ali H, Richardson R, Snyderman R, Oppenheim JJ (1998) Opiates transdeactivate chemokine receptors: delta and mu opiate receptor-mediated heterologous desensitization. J Exp Med 188:317-325.

Gurwell JA, Nath A, Sun Q, Zhang J, Martin KM, Chen Y, Hauser KF (2001) Synergistic neurotoxicity of opioids and human immunodeficiency virus-1 Tat protein in striatal neurons in vitro. Neuroscience 102:555-563.

Haribabu B, Richardson RM, Fisher I, Sozzani S, Peiper SC, Horuk R, Ali H, Snyderman R (1997) Regulation of human chemokine receptors CXCR4. Role of phosphorylation in desensitization and internalization. J Biol Chem 272:28726-28731. 
Hauser KF, El-Hage N, Buch S, Berger JR, Tyor WR, Nath A, Bruce-Keller AJ, Knapp PE (2005) Molecular targets of opiate drug abuse in neuroAIDS. Neurotox Res 8:63-80.

Hauser KF, El-Hage N, Buch S, Nath A, Tyor WR, Bruce-Keller AJ, Knapp PE (2006) Impact of opiate-HIV-1 interactions on neurotoxic signaling. J Neuroimmune Pharmacol 1:98-105.

Hauser KF, El-Hage N, Stiene-Martin A, Maragos WF, Nath A, Persidsky Y, Volsky DJ, Knapp PE (2007) HIV-1 neuropathogenesis: glial mechanisms revealed through substance abuse. J Neurochem 100:567-586.

Hemstapat K, Smith MT, Monteith GR (2004) Measurement of intracellular $\mathrm{Ca}^{2+}$ in cultured rat embryonic hippocampal neurons using a fluorescence microplate reader: potential application to biomolecular screening. J Pharmacol Toxicol Methods 49:81-87.

Hu S, Sheng WS, Lokensgard JR, Peterson PK (2005) Morphine potentiates HIV-1 gp120-induced neuronal apoptosis. J Infect Dis 191:886-889.

Kaul M, Lipton SA (2006) Mechanisms of neuronal injury and death in HIV-1 associated dementia. Curr HIV Res 4:307-318.

Khan MZ, Brandimarti R, Patel JP, Huynh N, Wang J, Huang Z, Fatatis A, Meucci O (2004) Apoptotic and antiapoptotic effects of CXCR4: is it a matter of intrinsic efficacy? Implications for HIV neuropathogenesis. AIDS Res Hum Retroviruses 20:1063-1071.

Khan MZ, Shimizu S, Patel JP, Nelson A, Le MT, Mullen-Przeworski A, Brandimarti R, Fatatis A, Meucci O (2005) Regulation of neuronal P53 activity by CXCR 4 . Mol Cell Neurosci 30:58-66.

Khan MZ, Brandimarti R, Shimizu S, Nicolai J, Crowe E, Meucci O (2008) The chemokine CXCL12 promotes survival of postmitotic neurons by regulating Rb protein. Cell Death Differ 15:1663-1672.

Kondo T, Shirasawa T, Itoyama Y, Mori H (1996) Embryonic genes expressed in Alzheimer's disease brains. Neurosci Lett 209:157-160.

Lazarini F, Tham TN, Casanova P, Arenzana-Seisdedos F, Dubois-Dalcq M (2003) Role of the alpha-chemokine stromal cell-derived factor (SDF-1) in the developing and mature central nervous system. Glia 42:139-148.

Li R, Luo C, Mines M, Zhang J, Fan GH (2006) Chemokine CXCL12 induces binding of ferritin heavy chain to the chemokine receptor CXCR4, alters CXCR4 signaling, and induces phosphorylation and nuclear translocation of ferritin heavy chain. J Biol Chem 281:37616-37627.

Marchese A, Chen C, Kim YM, Benovic JL (2003) The ins and outs of G protein-coupled receptor trafficking. Trends Biochem Sci 28:369-376.

McCarthy L, Wetzel M, Sliker JK, Eisenstein TK, Rogers TJ (2001) Opioids, opioid receptors, and the immune response. Drug Alcohol Depend 62:111-123.

Meucci O, Miller RJ (1996) gp120-induced neurotoxicity in hippocampal pyramidal neuron cultures: protective action of TGF- $\beta 1$. J Neurosci 16:4080-4088.

Meucci O, Fatatis A, Simen AA, Bushell TJ, Gray PW, Miller RJ (1998) Chemokines regulate hippocampal neuronal signaling and gp120 neurotoxicity. Proc Natl Acad Sci U S A 95:14500-14505.

Nath A, Hauser KF, Wojna V, Booze RM, Maragos W, Prendergast M, Cass W, Turchan JT (2002) Molecular basis for interactions of HIV and drugs of abuse. J Acquir Immune Defic Syndr 31 [Suppl 2]:S62-S69.

Navarro-Quiroga I, Chittajallu R, Gallo V, Haydar TF (2007) Long-term, selective gene expression in developing and adult hippocampal pyramidal neurons using focal in utero electroporation. J Neurosci 27:5007-5011.

Orsini MJ, Parent JL, Mundell SJ, Marchese A, Benovic JL (1999) Trafficking of the HIV coreceptor CXCR4. Role of arrestins and identification of residues in the c-terminal tail that mediate receptor internalization. J Biol Chem 274:31076-31086.

Patel JP, Sengupta R, Bardi G, Khan MZ, Mullen-Przeworski A, Meucci O (2006) Modulation of neuronal CXCR4 by the micro-opioid agonist DAMGO. J Neurovirol 12:492-500.

Pello OM, Martínez-Muñoz L, Parrillas V, Serrano A, Rodríguez-Frade JM, Toro MJ, Lucas P, Monterrubio M, Martínez AC, Mellado M (2008) Ligand stabilization of CXCR4/delta-opioid receptor heterodimers reveals a mechanism for immune response regulation. Eur J Immunol 38:537-549.

Pham CG, Bubici C, Zazzeroni F, Papa S, Jones J, Alvarez K, Jayawardena S, De Smaele E, Cong R, Beaumont C, Torti FM, Torti SV, Franzoso G (2004) Ferritin heavy chain upregulation by NF-kappaB inhibits TNFalpha-induced apoptosis by suppressing reactive oxygen species. Cell 119:529-542.

Phuapradit W, Taeepanichskul S, Jetsawangsri T, Chaturachinda K, Khupul- sup K, Kunakorn M (1996) Serum ferritin levels in normal and HIV-1 infected pregnant women. Aust N Z J Obstet Gynaecol 36:24-26.

Saito $T$ (2006) In vivo electroporation in the embryonic mouse central nervous system. Nat Protoc 1:1552-1558.

Saito T, Nakatsuji N (2001) Efficient gene transfer into the embryonic mouse brain using in vivo electroporation. Dev Biol 240:237-246.

Sammarco MC, Ditch S, Banerjee A, Grabczyk E (2008) Ferritin L and H subunits are differentially regulated on a post-transcriptional level. J Biol Chem 283:4578-4587.

Sharp BM (2006) Multiple opioid receptors on immune cells modulate intracellular signaling. Brain Behav Immun 20:9-14.

Shimizu S, Khan MZ, Hippensteel RL, Parkar A, Raghupathi R, Meucci O (2007) Role of the transcription factor E2F1 in CXCR4-mediated neurotoxicity and HIV neuropathology. Neurobiol Dis 25:17-26.

Steele AD, Henderson EE, Rogers TJ (2003) Mu-opioid modulation of HIV-1 coreceptor expression and HIV-1 replication. Virology 309:99-107.

Stumm R, Höllt V (2007) CXC chemokine receptor 4 regulates neuronal migration and axonal pathfinding in the developing nervous system: implications for neuronal regeneration in the adult brain. J Mol Endocrinol 38:377-382.

Sultana R, Boyd-Kimball D, Cai J, Pierce WM, Klein JB, Merchant M, Butterfield DA (2007) Proteomics analysis of the Alzheimer's disease hippocampal proteome. J Alzheimers Dis 11:153-164.

Sun Y, Cheng Z, Ma L, Pei G (2002) Beta-arrestin2 is critically involved in CXCR4-mediated chemotaxis, and this is mediated by its enhancement of p38 MAPK activation. J Biol Chem 277:49212-49219.

Szabo I, Wetzel MA, Zhang N, Steele AD, Kaminsky DE, Chen C, Liu-Chen LY, Bednar F, Henderson EE, Howard OM, Oppenheim JJ, Rogers TJ (2003) Selective inactivation of CCR5 and decreased infectivity of R5 HIV-1 strains mediated by opioid-induced heterologous desensitization. J Leukoc Biol 74:1074-1082.

Tabata H, Nakajima K (2001) Efficient in utero gene transfer system to the developing mouse brain using electroporation: visualization of neuronal migration in the developing cortex. Neuroscience 103:865-872.

Thompson K, Menzies S, Muckenthaler M, Torti FM, Wood T, Torti SV, Hentze MW, Beard J, Connor J (2003) Mouse brains deficient in $\mathrm{H}$-ferritin have normal iron concentration but a protein profile of iron deficiency and increased evidence of oxidative stress. J Neurosci Res 71:46-63.

Torti FM, Torti SV (2002) Regulation of ferritin genes and protein. Blood 99:3505-3516.

Toth PT, Ren D, Miller RJ (2004) Regulation of CXCR4 receptor dimerization by the chemokine SDF-1alpha and the HIV-1 coat protein gp120: a fluorescence resonance energy transfer (FRET) study. J Pharmacol Exp Ther 310:8-17.

Tran PB, Miller RJ (2003) Chemokine receptors: signposts to brain development and disease. Nat Rev Neurosci 4:444-455.

Tsai JW, Chen Y, Kriegstein AR, Vallee RB (2005) LIS1 RNA interference blocks neural stem cell division, morphogenesis, and motility at multiple stages. J Cell Biol 170:935-945.

Verde Méndez CM, Díaz-Flores JF, Sañudo RI, Rodríguez Rodríguez EM, Díaz Romero C (2003) Haematologic parameters in opiate addicts (in Spanish). Nutr Hosp 18:358-365.

Vidal R, Ghetti B, Takao M, Brefel-Courbon C, Uro-Coste E, Glazier BS, Siani V, Benson MD, Calvas P, Miravalle L, Rascol O, Delisle MB (2004) Intracellular ferritin accumulation in neural and extraneural tissue characterizes a neurodegenerative disease associated with a mutation in the ferritin light polypeptide gene. J Neuropathol Exp Neurol 63:363-380.

Woerner BM, Warrington NM, Kung AL, Perry A, Rubin JB (2005) Widespread CXCR4 activation in astrocytomas revealed by phospho-CXCR4specific antibodies. Cancer Res 65:11392-11399.

Yang L, Jackson E, Woerner BM, Perry A, Piwnica-Worms D, Rubin JB (2007) Blocking CXCR4-mediated cyclic AMP suppression inhibits brain tumor growth in vivo. Cancer Res 67:651-658.

Zandman-Goddard G, Shoenfeld Y (2007) Ferritin in autoimmune diseases. Autoimmun Rev 6:457-463.

Zecca L, Berg D, Arzberger T, Ruprecht P, Rausch WD, Musicco M, Tampellini D, Riederer P, Gerlach M, Becker G (2005) In vivo detection of iron and neuromelanin by transcranial sonography: a new approach for early detection of substantia nigra damage. Mov Disord 20:1278-1285. 